NEW LITERARIA-

An International Journal of Interdisciplinary Studies in Humanities

Volume 3, No. 1, January-February, 2022, PP. 30-36

ISSN: 2582-7375

DOI: https://dx.doi.org/10.48189/nl.2022.v03i1.004

www.newliteraria.com

Representation of Cultural Identity in Harishankar Jaladas' Sons of the Sea

\title{
Nurul Islam
}

\begin{abstract}
Simply speaking, culture is the shared customs, ideas, beliefs, etc. of a particular group of people in a society or country. In his novel Jalaputra, which is translated into English as Sons of the Sea, Harishankar Jaladas describes about several rituals, Monosha Puja, gods and goddesses of fishermen, their prayers and recitation of manuscript etc. The fishermen of North Patenga lead their lives depending upon the mercy of the sea and they are also dependent on the moneylenders. They can never get release from the oppression of the moneylenders. Despite their misfortunes and oppression, these hard-working fishermen too have their own cultures and rituals, hopes and desires, moments of well and woe, love and hatred that are very much reflected in the novel. These fishermen are very aware of their cultural unity and identity. They have a strong respect for their own institutions and a firm belief in the rightness of their ideals. A strong bond of kinship and cooperation is also discernible among them. Fishermen also have their folklore, songs and stories. During their fishing work, they derive mental pleasure by singing folksongs on themes of everyday life. This paper will explore their rituals, customs and cultural elements that constitute them as separate entities. It will also discover several religious rituals and festivities which are the main magnetisms of this particular fishing community.
\end{abstract}

Keywords: Culture, Fishermen, Ritual, Cultural Identity, Harishankar Jaladas.

The culture of people in a society includes the values, customs, traditions, practices, attitudes, and beliefs etc. It is a dynamic process. It grows and evolves through generation after generation. Culture is also a source of identity. Despite their diverse roots and origins, people of a community have a common identity only because of their culture.

Cultural interactions form a person's identity. According to Stuart Hall, culture is a means of building identity that brings meaning in a person's life. The notion of 'culture' is very complex. Raymond Williams (1983) says, "Culture is one of the two or three most complicated words in English language" (Williams, 1983, p. 87). He describes 'culture' in its different manifestations in the nineteenth century:

It came to mean, first, 'a general state or habit of the mind, having close relations with the idea of human perfection. Second, it came to mean 'the general state of intellectual development, in a society as a whole'. Third, it came to mean 'the general body of the arts'. Fourth, later in the century, it came to mean 'a whole way of life, material, intellectual and spiritual. (Williams, 1960, p. xiv)

Williams' fourth view of culture is all-encompassing as it includes almost every aspect of a 
man's life.

In his praised novel Jalaputra, which is translated into English as Sons of the Sea, (2014) Harishankar Jaladas depicts the hard-working life of the fishermen of North Patenga, their society, oppression, festivals, rituals, pujas, recitation of manuscript and almost everything about their daily lives. The fishermen sing or listen to various songs like Bhatiali, Baul, Kirton, Shari, Jari etc. Their society is controlled by social leaders like Bijonbihari bahaddar (1) and they lead a community life. They solve their problems through discussions and mutual understanding between fishermen of their locality. When Bhuban's land is unlawfully occupied, she comes to Bijanbihari and pleads, "Dhonbaisha's Baap built a hut occupying our vacant homestead. This land belongs to my father-in-law. I am helpless. Bahaddar, please help me in my trouble" (Jaladas, 2014, p. 77). Finally, an arbitration was called to settle their dispute. In their arbitration, the plaintiff has to provide pan (2), bidi (3) etc. as per their custom.

Fishing is one of the primitive professions in Bengal. From time immemorial, a lot of people have depended on fishing and associated occupations for their livelihood. Traditionally, fishermen are Hindus and in the cast hierarchy they are ranked the lowest, but they believe their profession to be sacred. Hunter and Risley ranked them in the lowest position in the caste hierarchy among the Hindus. Although fish is a popular food and it is highly valued Bengal, the general dislike for the fishermen proves to be a cultural paradox.

Fishermen are very aware of their cultural harmony and they have a strong respect for their institutions and a belief in the appropriateness of their values. They observe some particular rituals and ceremonies. They always try to appease the $M a$ Ganga (mother Ganges) for helping them in their catch and keeping them safe during their fishing. Mother Ganges is the supreme deity to the fishermen. In the month of Ashar (4), all men and women worship Mother Ganges, the goddess of fish. Fishing is not only a profession but also a way of life for many of them.

Women of fishing community are very religious. Throughout the year, they worship gods and goddesses, perform pujas, and rituals. Bhuvoneswari's character shows the unwritten but acknowledged custom of the fishing communities. She used to wear coloured sari and shakha (5) even five years after the disappearance of her husband. She waited with a hope of her husband's return. Jaladas exposes their custom when he says, "If the husband disappeared in the sea, the wife could lead a married woman's life for twelve years. This was the custom of the Jaladas community" (Jaladas, 2014, p. 26). Though their custom in their community allows the widows to marry, most of them don't marry because of their children. After 12 years' waiting, they are to wear white borderless dhoti.

The fishermen in this novel prefers ethics to instinct. That is why they threw out Dindayal master when he is caught for adultery though they knew that it would stop their children's education. Dindayal and Mangli had to undergo the punishment called Dhendheri in which Dindayal's hair was shaved and a good length of Mangli's hair was also cut. With strings of shoes around their necks, they were made to walk from home to home.

The fishermen's community usually has many children but they enjoy little childhood. Jaladas (2014) expresses the true condition of education and role of women in the novel, "Education is a luxury to the fishermen; women among them are born to cook for the family and give birth to children every year. By the time the fishermen's sons cross ten or twelve they have to go to fish in the sea or canals or marshes" (p. 10).

Again, early marriage is another tradition in their community. The central character Bhuvoneswari was married at the age of nine. The novelist says, 
When a fishermen's daughter gets married, she is quite green. The boys are also just past their adolescence. When the two bodies come closer, they fiddle with them. The callow youths make unsuccessful attempts; the girls run off frightened and take shelter with their mother-in-law who understand the problem. They also had been through similar trying time in their own life. (Jaladas, 2014, p. 11)

Fishermen have to spend a lot of time on water due to their profession. Many of them die of snakebites during their aquatic profession. So, Manasha (6), the goddess of snakes, is the chief deity. They always try to appease Manasha to avoid snakebites. Throughout the month of Sraban (7), every family worship Manasha. Manasha puthi (8) is recited every night in one house or the other. This recital is attended by songs of separation. Most of their pujas and rituals remind us that man remembers or seeks help from divine power mostly in their time of crisis.

With great zeal, the fishermen observe the last day of Chaitra (9) and its following day i.e., the first day of Baisakh (10). Actually, these are the months of crises for them. On the last day of Chaitra, Chaitrasankranti (11) is celebrated with much devotion. Women give their hard savings to buy necessary items. Aunts, mothers and grandmothers make khai (12)-muri (13), roll moa (14)-naru (15) and other food items. Again, the children collect different leaves and bushes and pile them in the yard. Every woman who has borne children facing east fires up the piled items with reverence in order to pray for their children's welfare. This system is called jak (16). They also observe Shani puja (17) on Saturday. Shani is derived from Saturn and he is worshipped to drive away evil.

Panchalla is a meeting for marriage permission. In the fishermen's community, when one is to be married, the permission of the community is required. For this purpose, important members of the community gather and a discussion, they give the permission. Pan, betel-nut, lime-khair (18) and bidis are also served among them (Jaladas, 2014, p. 125). Besides, in their marriage ceremony, various rituals like namanto marriage (19) and bashie bie (20) are also observed.

Fishermen have their particular folklore, history, songs and literature that carry information about their beliefs. During their work they derive mental happiness by singing folksongs like bhatiyali and shari songs. The cultural elements of the fishing community constitute them as different entities. The themes of most of these songs are taken from their everyday life. To cite one example from the text, we can take a look at the sad and poor fisherman Jayanta who has become very indifferent to life after his first wife's death. Though he remarried Pakhibala, a deep indifference sometimes possessed him. Sitting on the verandah, Jayanta hummed sad songs of separation:

The bird that I cared for most left me,

I can't bear the pang of separation from the bird.

Is there a friend who will catch the bird for me?

It responded to any name that I used to call it.

How could that bird breaking chain fly away!

I am lost and can't stay in home. (Jaladas, 2014, p. 92)

We find a similar kind of theme in Manik Bandyopadhyay's "The Boatman of the Padma". When discouraged Ganesh sings a song with his unskilled voice, Dhananjay and Kuber listen attentively to the lyrics. In the words of the novelist, "The theme of the song concerned the deep-seated problem of why one does not get one's beloved. It was no simple song" (Bandyopadhyay, 2012, p. 8).

The author has beautifully delineated the society of the fishermen and their cultures with much care and importance. These fishermen have their own cultures but they are also influenced by the cultures of the major people of Bangladesh. As a result, they not only sustain 
their pure country cultures but also develop an assimilation with the cultures of the upper strata of society. The recital of Manasha Puthi and Manasha puja is a very popular familiar festival of Bangladesh. In Bangladesh, Manasha puja is observed in Hindu families in the month of Sraban. In the rainy season, land and water bodies are infested with snakes. People become victim of snake-bites and die. To protect themselves from this danger, people pray to Manasha, the goddess of snake. As the fishermen have to spend most of the time on water, Manasha becomes their chief deity. The novelist has perfectly presented their devotion:

The goddess Manasha is their chief deity. They have great dread for Manasha, the goddess of snakes. They have great respect for her, too. Snakes are fierce aquatic creatures. The fisher men are aquatic, too. Many fishermen die of snakebites. They believe that if they can keep goddess Manasha appeased, they can have respite from the fury of snakes. So, throughout Sravan every fishing household worships the goddess Manasha ceremoniously. Every night Manasha puthi is recited in one house or the other. (Jaladas, 2014, p. 3)

The loveboy (21) is the main attraction of this recital. He is paid for his dance as per their tradition. Dressed up as woman, he has to dance with the recital every night and entertain people.

Folk belief is also expressed in different forms in the novel. The fishermen draw two big human eyes on their boats. They do so with a belief that with these eyes their boats will search their nets in the deep sea. In the month of Ashar on Tuesday, these fishermen observe Gangapuja with the help of their Brahmin priest. Clad in clean dresses, everyone participates in this ceremony. On the occasion of this particular puja, an animal is also sacrificed as a custom.

The fishermen maintain their social system in every possible way. In the month of Chaitra, the bahaddars decide who will cooperate with whom in setting nets throughout the year. This system is known as haja. Everyone takes care to honour this verbal annual contract because if anyone violates it, he is ostracised and prevented from fishing. Though the fishermen are illiterate, with the help of their Brahmin priest they consult panjika (22) and they follow it. Their Brahmin priest fixes their date and time for inaugural fishing for the year. Consulting the panjika, he also decides 'the most suitable day for worshipping Mother Ganges' (Jaladas, 2014, p. 57).

Hookah, tobacco, biri and ganja (23) are the most common drugs among the fishermen of both sides of Bengal. They also use it to keep them warm in the cold weather during their fishing. When Purnachandra's sons were ready to set out for fishing, Jaladas describes their drugs: "On the bhar (24) tobacco, panta (25), curry, hookhah and water pitchers had been loaded" (Jaladas, 2014, p. 107). In Manik Bandyopadhyay's "The Boatman of the Padma", Ganesh, Kuber and Dhananjay take hookah to avoid shivering cold and get energized. Bandyopadhyay describes, "They took turns at the hookah until the tobacco was completely charred. The boat had advanced quite far by now" (Bandyopadhyay, 2012, p. 7). Often this hookah works as a cordial reception among them. We find such kind of reception in "A River Called Titash". Reaching the village of Nayakanda, Kishore starts conversation with a man at the ghat and offers him hookah. After a while, the man too offers his own hookah to Kishore: "I've smoked your hookah---now you smoke my daughter's hookah". (Mallabarman, 1993, p. 37)

Shadbhakhan (26) is another occasion to celebrate pregnancy. On this occasion, pregnant women are ritually given their desired food. This is arranged with a prayer for smooth delivery and the arrival of a healthy baby. The expectant mother is dressed up in new clothes. Everyone gives her some food one by one. 
Dress is another important aspect of culture and cultural identity. In conformity with their social status and profession, the 'sons of the sea' are used wear very simple clothes in their everyday life. They usually wear dhotis hanging up to their knees. A gamcha (27) is always seen hanging from the shoulder of a fisherman. They are seen to wear fatua (28) on different social occasions or during monsoon and winter. Some wear shirts. During their fishing, they wear a gamcha on the loin and a torn shirt. While fishing they make a turban of their dhoti and put biris and matches inside it. Their simple clothing exposes their lower economic condition as well as their traditional cultural identity.

Despite their poverty-stricken life and survival life struggle, they earnestly try to stick to their cultural life. Though Bhuvan is passing a very hard time, she expresses her wish to bring her niece to her house for naior (29). According to the rural tradition of Bengal, naior is the name given to a daughter's coming from her husband's house to her parental home or relations after her marriage.

The drug items are usually taken by the male members of this community. But there are many food items that are very common and popular among all of them. A few among them are Khai, moa, naru, gur (30), atkaraia (31) etc. Pachan (32) is another item which is required as a customary rule on the day Chaitrasankranti. On the occasion of Chaitrasankranti, these foods are prepared with much enthusiasm: "Mothers, grandmothers, aunts waking up all night make khai-muri, roll moa-naru and prepare atkaraia" (Jaladas, 2014, p. 48).

We have a few other novels dealing with the life of the fishermen. Though the fishermen work hard to supply fish in our dishes, they are often disregarded and deprived of their minimum rights and social status. However, the Bangla litterateurs didn't fail to recognize their importance and portray their lives and culture. Manik Bandopadhyay first demonstrated the life of fishermen in 1936 in his renowned Bengali novel Podda Nodir Majhi which is later translated into English as The Boatman of the Padma. The novel A River Called Titash delineates the lives of the Malo fisherfolk on the banks of the river Titash in Comilla of the then East Bengal. Adwaita Mallabarman presents the rich oral culture of the Malos, their folksongs, beliefs and rituals, their festivities along with their struggling lifestyle. To some extent, Mallabarman has written the history of his community in the form of a story. To justify this, we can quote his words: "But its banks are imprinted with stories of a mother's affection, a brother's love, the caring of a wife, a sister and a daughter. That history perhaps some know, perhaps some don't. Still that history is true and real" (Mallabarman, 1993, p. 21)

So far three significant films have been made on the lives of the fishermen in Bengali films. These are Ritwik Ghatak's Titas Ekti Nadir Naam, Rajen Tarafdar's Ganga and the last of the trilogy is Gautam Ghosh's Padma Nadir Majhi. These films are based on the Bengali novels of the same names. These films beautifully portray the river-centric life of the fishermen and work as their cultural document.

Harishankar Jaladas's novel Sons of the Sea, as literary masterpiece, is the authentic reflection of the society of Jaladas fishing community and their culture. The specific characteristics of their social, religious and cultural features construct their distinctive identity which is rich and unique. However, the worth of culture cannot be demarcated by its size. Nevertheless, if a culture is prevalent widely or kept in reserve within a small region, old or young, or has transformed over time or remained the same, each culture can teach us about others, ourselves, and the global community as a whole.

\section{Notes:}


1. Bahaddar: a solvent and powerful fisherman

2. Pan: betel leaf

3. Biri: cheap cigarette made of tobacco wrapped in dry leaves.

4. Ashar: third month of Bengali calendar

5. Shakha: white bangle made of conch shell

6. Manasha: snake goddess

7. Sravan: the fourth month in Bengali calendar; this month falls in monsoon.

8. Manasha Puthi: a kind of folk text on goddess Manasha and her wrath

9. Chaitra: last month of Bengali calendar

10. Baishakh: first month of Bengali calendar, from mid-April to mid-May

11. Chaitrsankranti: celebration of the last of the year according to the Bengali calendar

12. Khai: popcorn like snack prepared from rice.

13. Muri: puffed rice

14. Moa: a ball of sweetened puffed rice

15. Naru: a ball of sweetened rice poweder, etc

16. Jak: an event to expose children to a smoke of medicinal herbs

17. Shani puja: worship of Shani

18. Khair: a kind of vegetable extract taken with betel leaf

19. Namanto marriage: a kind of marriage where the bride is brought to the bridegroom's house for the marriage ceremony.

20. Bashie bie: the morning rituals in a Hindu marriage following the main wedding rituals held at night.

21. Loveboy: hired young boys who dress up as young women and sing and dance amorously to entertain the crowd gathered on the eve of puthi recital.

22. Panjika: an almanac with a list of auspicious as well as inauspicious days.

23. Ganja: preparation of marijuana for smoking

24. Bhar: a bamboo pole put on shoulders to carry fish

25. Panta: stale rice, dipped in water and leftover night for eating in the next morning

26. Shadbhakhan: a ritual to celebrate pregnancy

27. Gamcha: towel

28. Fatua: short-sleeved vest

29. Naior: a daughter's visit to her parental home or relations after marriage.

30. Gur: molasses or treacle

31. Atkaraia: a collection of 8 types of seeds like pulse, been, pumkin seed etc.

32. Pachan: cooked mixed vegetables.

\section{References}

Williams, Raymond. (1963). Culture and Society: 1780-1950. New York: Anchor Books.

Williams, Raymond. (1976). Keywords. New York: Oxford University Press.

Mallabarman, Adwaita. (1993). A River Called Titash (Kalpana Bardhan, Trans.). University of California Press. (Original work published 1956).

Jaladas, Harishankar. (2014). Sons of the Sea (Quazi Mostain Billah, Trans.). Academic Press and Publishers Library. (Original work published 1955).

Bandyopadhyay, Manik. (2012). The Boatman of the Padma, (Ratan K. Chattopadhyay, Trans.). Orient Blackswan Private Limited. (Original work published 1936).

Benet-Martínez, V. (2012). Multiculturalism: Cultural, social, and personality processes. In Deaux, K, M, Snyder, (Eds.) The Oxford Handbook of Personality and Social Psychology. Oxford University Press. 


\section{$\underline{\text { Bio-note }}$}

Nurul Islam is currently pursuing his Ph.D. research work from Sidho-Kanho-Birsha University. He has completed his M.A. in English and B.Ed. from the University of Gour Banga. His research area includes Subaltern Studies, Indian English Literature and Postcolonial Studies. Besides, he has also attended several national and international webinars, econferences and workshops. 